\title{
ELECTRONIC WORTH OF MOUTH AND DESTINATION IMAGE AND IT'S AFFECTS ON VISITING TOURISTS DECISION IN THE TIKUS ISLAND
}

\author{
Eska Prima Monique Damarsiwi ${ }^{1 *}$ and Wagini ${ }^{2}$ \\ ${ }^{1,2}$ Universitas Dehasen, Bengkulu, Indonesia
}

\begin{abstract}
Tourism is one of the mainstays to obtain the country's foreign exchange and its development is expected to spur Indonesia's economic growth. Every area in Indonesia has the potential to be used as a tourist attraction, as well as the area of Bengkulu City which has exotic marine tourism, namely in Tikus Island. The purpose of this study was to analyze the effect of Electronic Word of Mouth (eWOM) on tourist visiting decisions to Tikus Island and to analyze the influence of Destination Image on tourist visiting decisions to Tikus Island and to analyze which variables had the most dominant influences of visiting tourists to Tikus Island. This research also has an output target that is expected to be achieved, including this research can provide input for the government and employers to find out Electronic Word Of Mouth (eWOM) and Destination Image so that it can ultimately increase tourist interest.. This research was conducted in the area of tourist objects that are often visited by local and outside tourists in the city of Bengkulu. The sampling method in this study is a survey using a cross sectional questionnaire and the sample used is 385 respondents. The results of the research are Concern for Other independent variables, Helping the company and destination image partially have significant positive influence on visiting decisions. While Expressing positive filling variables did not have a significant effect on visiting decisions. However, simultaneously Concern for Other, Expressing positive filling, Helping the company and the destination image have a significant positive effect on the dependent variable of visiting decisions. While the destination image variable is considered as the dominant variable in influencing tourists visiting decisions to Tikus island Bengkulu

Keywords: Consumer Satisfaction, Destination Image, Electronic Word of Mouth, Visiting Decision
\end{abstract}

\section{INTRODUCTION}

The tourism industry according to Yoeti 2008 in Santoso 2009 is one of the mainstays to obtain State foreign exchange and the development is expected to spur Indonesia's economic growth. Bengkulu Province is one of the provinces directly adjacent to the Indonesian Ocean, precisely at 5040 '- 200' LS and 100040 '- 10400' BT. This Bengkulu Province region have exocratic maritime tourism, bay the existence of the Tikus Island (Sustirahmah.2013). Tikus Island is located to the west of Bengkulu City with a distance of $10 \mathrm{Km}$ from the center of Bengkulu City and directly connected to the Indian Ocean with a geographical location of $30^{\circ} 50^{\prime} 17.55$ "LS and $102^{\circ}$ 10'50,59" BT (http: // www. ppk-kp3k.kkp.go.id)

Although is not famous like the other tourist attraction, but natural beauty of the underwater panorama is a hidden pearl. Its Start from from Beach Tourism (Walking and Jogging on The Beach, Sun Bathing), Diving (Diving), Surfing (Surfing), Snorkeling (Observation from the surface of the water), Camping and Out Bond, Canoeing (Sailing), Sailing / Cruising (sailing / cruise ships), Bird Watching (Bird observation), Mangrove Tracking, Dolphin Watching (Watching Dolphins), Whale Watching (Watching Whales), Release of Hatchlings, Sport Fishing, Volly Beach,

* Corresponding author. Email address: ds.monique@gmail.com 
Refreshing, Culinary tourism, Jet Ski Sport (Sports Jet Ski), Sea Kayaking (Kayak on the Sea) (http://www.unib.ac.id). However, the existing potential has not been utilized properly and managed optimally, this can be seen from the results of the Bengkulu Province BPS data (2015) that economic development in Bengkulu is still very small and has not been able to reduce poverty which reaches $16 \%$ of the total population of 1.884 .788 people. In order to increase economic development, the government launched the Wonderful Bengkulu 2020 program that is in line with the Visit Indonesia program. So that it is expected to be able to boost the interest of local, national and foreign tourists to be able to visit Bengkulu. This is felt because the tourism sector is a sector that is able to provide a multidimensional effect, create jobs, reduce poverty and if it has been very advanced will be able to help Bengkulu Provincial PAD.

According to Santoso (2009) the local government has realized the potential of the coastal area of the city of Bengkulu, then made one of the strategic policies that is expected to be able to absorb not only local tourists but also national and international tourists. There are six focused forms of tourism planned namely coastal tourism, urban tourism, public tourism, water tourism, ecotourism tourism and port tourism. The development of tourism in the coastal area of the City of Bengkulu is expected to be able to increase Regional Original Revenue (PAD) and the welfare of the people of Bengkulu City and its surroundings. Whereas According to Spillane (1994) a tourist object or destination, must include 5 (five) important elements so that tourists can feel satisfied in enjoying their journey, namely: Attractions, Facility, Infrastructure, Transportasion. So that for the successful management of the tourism sector, the government needs to carry out management involving other parties or the private sector. As stated above, the government must be serious in improving strategic facilities and infrastructure such as airports, transportation insite and outside the city, telecommunications, immigration systems and rules that make it easier for developing business people in this sector.

Based on data from the Ministry of Communication and Information Technology (Kemkominfo) internet use in Indonesia in 2017 reached 112.6 million. With this achievement, Indonesia ranks 6 th in the world. Whereas according to the data obtained from the Association of Indonesian Internet Service Providers (APJII) until March 2015 there were $87.4 \%$ netizens to access social networks, then followed by browsing $68.7 \%$ and the last instant massaging 59.9\% (teknisi.news.viva.co.id). So that through the presentation of the data it can be stated that the majority of internet users use their time to access social media. Malita (2010) explains that social media is an evolution phenomenon, a shit in how people discover, read and share: news, information, content. Hennig - Thurau et. al., (2004), argues that Electronic Word Of Mouth is a positive or negative statement made by potential customers or former customers about the product or company, which is intended for many people and institutions via the internet. People are getting to know various kinds of applications and various tools that are easy to use, friendlier, free to use and use to (re) build. No matter what application they use to spend time using it.

Every consumer who has consumed a product will give their own assessment of the product, and cannot be influenced by others because the decision comes from themselves, if the consumer feels satisfied or dissatisfied then the consumer will give the review of the product to someone else who has an account disocial media, e-mail, blogs, and websites that have been there before. (Lee, Park, and Han, 2008). The involvement of consumers in providing responses and responses to the uploaded content as a media to find and exchange information is what is called Electronic Worth Of Mouth (eWOM).

According to research Jeonga et. al., (2011) which focuses on positive Electronic Worth of Mouth (eWOM) dimensions, they stated that the positive Electronic Worth of Mouth (eWOM) dimension can be seen through three dimensions, namely: Concern for The Others, Expressing Positive Feelings, Helping The company. While HenningThureau et.al., (2004) says there are eight dimensions of Electronic Word of Mouth 


\section{ELECTRONIC WORTH OF MOUTH AND DESTINATION IMAGE AND IT'S AFFECTS ON VISITING TOURISTS DECISION IN THE TIKUS ISLAND}

(eWOM) namely Platform Assistance, Venting Negative Feelings, Concern For Others Consumers, Extraversion / Positive Self Enhancement, Social Benefits, Economic Incentives, The Helping Company, and Seeking Advice. In this study the researchers chose to take 3 dimensions from eWOM namely Concern for the Others, Expressing Positive Feelings, Helping The Company.

According to Hanif (2010) destination image is the belief / knowledge about a destination and what is felt by tourists during the tour. Deep understanding about the destination image is believed to be able to make a significant contribution to in-depth knowledge in the field of tourism, such as tourist decision making and destination selection behavior (Fakeye and Crompton, 1991; Goodrich, 1978). Some researchers stated that the destination image can attract pre-visit visitors, even though they have never visited a tourist destination at all (Echtner and Ritchie, 2003; Henkel et al., 2006). However, the image formed by pre-visit visitors may change if the actual conditions of tourist destinations do not match what they expect.

Kotler (2000) explains that interest is an impulse, or strong internal stimulation that motivates actions where this drive is influenced by stimulus and positive feelings about the product. Some studies state that identification of attributes of a destination needs to be done to determine the important factors considered by tourists in deciding to visit a particular tourist destination (Echtner and Ritchie, 2003). Based on the opinions stated above, it can be concluded that visiting is an impulse that arises from within a person to act before making a decision to visit a tourist destination

Not many studies have tried to identify attributes that are considered important for tourists to a particular tourist destination in a destination that still does not have a good level of popularity (developing regions). For this reason, this study aims to investigate the factors considered important for tourists to visit a particular destination and its relation to the level of tourist satisfaction at a destination.

\section{LITERATURE REVIEW}

Visiting Decision

In relation to the world of tourism, purchasing decisions are assumed to be a visiting decision so theories about purchasing decisions are also used in visiting decisions. Consumer purchasing decisions are a process of fulfilling the need for goods and services. Usually consumer stimuli to buy are obtained from outside themselves, both in the form of marketing stimuli and stimuli from other environments. Consumer purchasing decisions can take place coherently in five stages, but not all of the consumers pass through these stages. The five stages include: introduction of problems, tracking information, evaluating alternatives, purchasing decisions and pre-purchase activities of consumers. Tourist satisfaction is an overall measure of tourist opinions on each destination quality (Prayag, 2008 in Coban, 2012). According to Yuksel et al. (2010) measure satisfaction with three items, first relates to whether or not tourists are happy with their decision to visit a tourism destination, second is the belief that choosing a related destination is the right thing, and thirdly the overall level of satisfaction during a tour to a tourism destination.

\section{Electronic Worth Of Mouth (eWOM)}

According to Kevin, Dwayne and Gremler in Hadi (2013) are positive and negative statements by potential, actual or former consumers regarding a product or company and distributed to others via the internet. Electronic Worth of Mouth (eWOM) is often referred to as viral marketing, a marketing technique used to spread a marketing message from a website or use social networking sites which can create exponential growth like a virus.

Three stages of eWOM according to Sumardi in Nugraha (2013) are Talking, Promotion, Selling (TAPS). Talking is the stage where a consumer talks about a product or company to other consumers. Promotion is when someone or group is not just talking about but also willing to introduce it to other consumers. Selling is a stage 
where someone or group sells a brand or product to someone else. One of the Electronic Worth of Mouth (eWOM) media commonly used by a person or company is social media. Hasan (2015) mentions that social media marketing is the practice of facilitating a dialoque, using various online platforms including blogs, professional and social networks, video and photo sharing, Wikis, forums and related web technologies to promote brands or introduce places they have visit.

In the study of Jasen et al (2009), microblogs are short comments that are usually sent to isolated networks. Microblogging is often called micro-sharing, microupdating, Twiterring (the most popular microbloging application) or other blogging terms. Jeonga et al (2011) divided the Electronic Worth of Mouth (eWOM) into three dimensions, namely: Concern for Other (concern for others), Expressing positive filling, Helping the company.

\section{Destination Image}

Image or image is an important element for a tourist destination. This is because the image is a picture of the conditions of the elements contained in the tourist attraction that was created in a long time. Therefore, tourists usually use the destination image as one of the guidelines in making decisions leading to the tourism object.

According to Arafat (2006) Image or image can be interpreted as a public perception of the identity of the company or association. The destination image in this study refers to brand image theory, where the brand can provide an overview of a product where the brand cannot be separated from its product, namely a tourist destination.

The results of research conducted by Semuel and Lianto (2014) explained that Brand Image proved to have a significant effect on Buying Interests. This means that a product with a brand that is good or good, consumers are more likely to repeat purchases on that brand. For that Semuel and Lianto (2014) explain that the high and low brand image has an impact on buying interest. Based on the research results of Musay (2013), it was explained that Brand Image has a significant influence on Purchasing Decisions.

Previous research has found that destination images have a significant influence on destination selection by pre-visit tourists, travel-related decisions, and visit behavior intentions (Echtner and Ritchie, 2003; Henkel et al., 2006; Rittichainuwat et al., 2001) . The destination image also has a significant effect on purchasing behavior during the visit and the level of satisfaction with the destination (Chon, 1990).

Destination images are formed when tourists create mental images of a destination based on information they receive from actual experience as well as from advertising media, and other marketing media (Gartner, 1994). Individuals can develop a destination image even without personal experience in a destination. Destination images formed before a visit may change after individuals make actual visits, because the image of the destination before the visit may include information that is less precise or personal bias (Balogu and McCleary, 1999; Beerli and Martin, 2004).

In line with the Wonderful Bengkulu visit 2020 program launched by the Bengkulu Provincial Government, the tourism sector is one of the leading sectors in increasing regional economic growth and society. (https://travel.detik.com/advertorialnews) Starting in 2017 Bengkulu starts heading to the Bengkulu visit 2020, by making 7 events exposing Bengkulu tourism potential both natural tourism, culinary and cultural arts to support the Bengkulu 2020 program visit

According to Governor Rohidin Mirsah there are at least 7 tourism events that we will hold, the activity focuses more on events that expose the natural, culinary, and cultural arts of Bengkulu Province, which will come from all regencies and cities in Bengkulu Province, which The peak will be in 2020, at the 52nd anniversary of Bengkulu Province, which will be accompanied by 52 Wonderful Bengkulu festival events (https://bengkuluprov.go.id/tahun-2017-bengkulu-bersiap-menuju-visitwonderfull- bengkulu-2020). 


\section{ELECTRONIC WORTH OF MOUTH AND DESTINATION IMAGE AND IT'S AFFECTS ON VISITING TOURISTS DECISION IN THE TIKUS ISLAND}

Starting to improve Bengkulu Province to welcome the Wonderful Bengkulu visit program in 2020, it is hoped that it can improve the image or image of tourists towards Bengkulu Regency and Province tourism objects, so that it can create a strong brand image in the minds of tourists and be positively accepted. Currently Pulau Tikus is one of the islands prepared for the Bengkulu Wonderful visit program 2020. So that when Pulau Tikus has a strong and positive image in the minds of consumers, the Tikus Island will always be remembered and the possibility of consumers returning. So in this case if a good image is formed for Pulau Tikus tourism objects, consumers will be interested in visiting and making repeat visits.

\section{CONCEPTUAL FRAME}
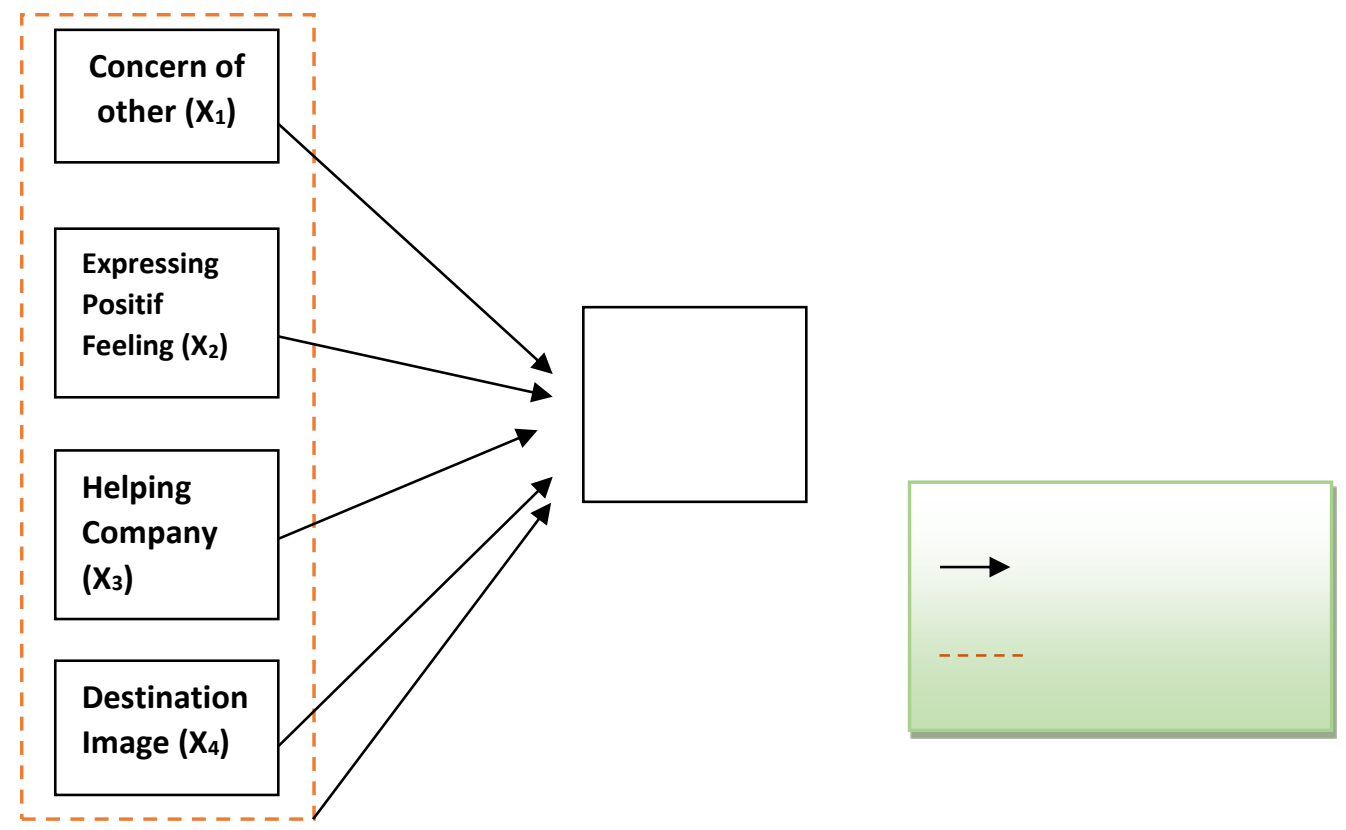

Figure 1 Analysis Frame

\section{RESEARCH METHOD}

This research was conducted in the area of tourist objects that are often visited by local tourists and outside tourists in the city of Bengkulu. The researcher will distribute the questionaire to the respondents who are currently at the tourist attractions. Data collection will be carried out for 3 months in 2018.

This analysis technique which is used is the quantitative analysis technique which is the double regresion linear that is use to count the influence and make linear equation which are abel to be reference to project $\mathrm{Y}$ variable (visiting decision) base on the $\mathrm{X}_{1}$ variable (Concern for Other), the $\mathrm{X}_{2}$ variable (Expressing positive filling), the $\mathrm{X}_{3}$ variable (Helping the company), the $\mathrm{X}_{4}$ variable (Destinasion Image).

The research method in this study is a survey using a cross-sectional questionaire. The type of data used is primary data. The way to collect primary data is by distributing questionaires. In this study the population is tourists who visit the City of Bengkulu. The sampling method used the accidental sampling technique, namely the taking of respondents as a sample based on coincidence, that is anyone who accidentally meets with a researcher can be used as a sample if the person met is in accordance with the criteria of the data source. The criteria determined by the researcher are:

Respondents are all consumers, both local residents and tourists in the tourist area of Bengkulu City.

1. Respondents are consumers who already know the Tikus Island or those who do not know 
2. Reponden are consumers who can use the internet or other social media accounts.

Rao Purba (1996), said that in determining the sample size, if the population is large and the number is unknown, then the formula is used as follows:

$$
n=\frac{Z^{2}}{4 M o e^{2}}
$$

Information:

$\mathrm{n}=$ Number of Samples

$\mathrm{Z}=$ Normal distribution level at a significant level of $5 \%=1.96$

Moe $=$ Margin of error which is the maximum error rate of sampling that can still be tolerated or desired by $5 \%$ or 0.05

According to Arwiedya in Nugraha (2013), the influence factor in purchasing decisions is online word of mouth by revealing that Electronic Worth of Mouth (eWOM) is interpersonal communication between two or more individuals where everyone has influence over continuous purchases using internet media or web. Ali Hasan (2014) mentions social media marketing is the practice of facilitating a dialoque, using various online platforms including blogs, professional and social networks, video and photo sharing, wikis, forums and related web technologies to promote. Jeonga et al (2011) devide Electronic Worth of Mouth (eWOM) into three dimension: (1) Concern for Other. (2) Expressing positive filling, (3) Helping the company.

Base on the word above the writer summarizes the hypotesis:

Ha1 : $\quad$ Concern for Other has a positife influence to tourism visiting decision to Tikus Island

Ha2: $\quad$ Expressing positive filling has a positife influence to tourism visiting decision to Tikus Island

Ha3: Helping the company has a positife influence to tourism visiting decision to Tikus Island

The destination image in this study refers to brand image theory, where the brand can provide an overview of a product where the brand cannot be separated from its product, namely a tourist destination.Based on research results by Semuel and Lianto (2014) explained that Brand Image proved have a significant effect on Buying Interests. This means that a product with a good brand will attract buyers to repeat purchases on that brand. Base on those conclusions explain that the high and low brand image has an impact on buying interest. Musay (2013), it was explained that Brand Image has a significant influence on Purchasing Decisions. Therefore based on the previous research results, the writer concludes the fourth and fifth hypothesis

$\mathrm{Ha} 4$ : Destinasion Image has a positife influence to tourism visiting decision to Tikus Island

Ha5: $\quad$ Concern for Other (X1), Expressing positive filling(X2), Helping the company (X3) and destinasion image simultaneously influence to tourism visiting decision to Tikus Island

Based on the formula above, the number of samples to be used by researchers is 385 respondents scattered throughout the tourist areas of Bengkulu City. Hypothesis testing in this study uses a simultaneous test (F-test) and partial test (t-test) to determine the effect between independent variables $(\mathrm{X})$ and the dependent variable $(\mathrm{Y})$ and test the coefficient of determination (R2). The classic assumption test in this study is the normality test, heterocedasticity test, multicollinearity test and autocorrelation test.

\section{RESULT AND DISCUSSION Validity test}

To find out whether the validity of research data is valid, a comparison of the $r$ table values with $r$ count is done. If the value of $r$ count is greater than the value of $r$ table, it can be concluded that the research data is valid. From the spss results it can be 


\section{ELECTRONIC WORTH OF MOUTH AND DESTINATION IMAGE AND IT'S AFFECTS ON VISITING TOURISTS DECISION IN THE TIKUS ISLAND}

seen that $r$ value $\mathrm{Y} 1.1(0.709)$; Y1.2 (0.754); Y1.3 (0.755); Y1.4 (0.667); Y1.5 (0.747); X1.1 (0.767); X1.2 (0.818); X1.3 (0.815); X1.4 (0.733); X2.1 (0.824); X2.2 (0.83); X2.3 (0.792); X2.4 (0.732); X3.1 (0.844); X3.2 (0.905); X3.3 (0.872); $\quad$ X3.4 (0.857); X4.1 (0.842); X4.2 (0.906) X4.3 (0.910); X4.4 (0.711) and the $r$ table value for $\mathrm{n}=385$ and $\alpha=5 \%$ is 0.0998 . So that it can be concluded that the question variable in the study is valid this is because the calculated $r$ value is greater than $r$ table and the significance is smaller than 0.05 .

\section{Reability Test}

Reability testing in this study is seen from the value of Croncbach's Alpha generated from data processed using SPSS software. According to George and Mallery (2003), to measure the level of reliability of instruments based on Cronbach'Alpa. From the spss results, it can be seen that the value of Croncbach's Alpha $=0.900$ so that it can be concluded that the research data is very good because the value of Croncbach's Alpha is above 0.80 . So the data can continue to be used to the next test.

\section{CLASSIC ASSUMPTIONS}

Before implementing multiple regression testing, the existing data must be free from classic assumptions, namely:

1. Normality Test

To test the normality of the data can be done by Kolgomorof-Smirnov test. If the $\mathrm{P}$-value $\geq \alpha$, then the data is normally distributed, whereas if the P-value $\leq \alpha$, the data is not normally distribut. From the results of the table above it can be seen that the Pvalue in each variable is: 0.458 (KPBJK variable), 0.550 (CONCOF variable), 0.210 (EXPRES variable), 0.158 (HELP variable), 0.230 (IMAGE variable). The P-value value is greater than 0.05 , so it can be concluded that the research data is normally distributed. After knowing the results that the data is normally distributed, the research data can be continued to be used in subsequent test

2. Multicollinearity test

The SPSS output results show that the VIF value of each independent variable is far below 10, namely CONCOF $(\mathrm{X} 1)=1,327$, EXPRES (X2) $=1,549, \operatorname{HELP}(\mathrm{X} 3)$ $=2,111$, IMAGE $(\mathrm{X} 4)=1,870$. It can be concluded that there is no multicollinearity between the independent variables Concern for other (CONCOF), Expressing Positive Feeling (EXPRES), Helping the Company (HELP), Destination Image (CITRA).

3. Autocorrelation Test

To be able to find out whether the research data is free from autocorrelation, we must first know the value of the Durbin-Watson table which will later be compared with the calculated Durbin-Watson value. After looking at the SPSS output for $\alpha=$ $0.05, \mathrm{k}=4$ and $\mathrm{n}=385$ obtained the value of $\mathrm{dL}=1.81577, \mathrm{dU}=1.84758$ and $4-\mathrm{dU}=$ $2.15242,4-\mathrm{dl}=2.18423$. Because the value of durbin watson of 2.133 lies between $\mathrm{dU}$ and 4-dU, it can be concluded that the model is free from autocorrelation.

4. Heteroscedasticity test

Heterokedastic testing aims to test whether in the regression model variance occurs from residual inequalities, one observation to another observation. In this study Heterokedastis testing uses the Glejser test, while the basis for testing decisions is seen from the significance value of the SPSS output in the Coefficient table. If the value of Significance is greater than $\alpha(0.05)$ then heterokedastic does not occur. The test results are as follows:

From the SPSS output, it can be seen that the significance value of the CONCOF variable $(X 1)=0.241, \operatorname{EXPRES~}(X 2)=0.111, \operatorname{HELP}(X 3)=0.460$, IMAGE $(\mathrm{X} 4)=0.141$ greater than $\alpha(0.05)$ so that it can be concluded that the data does not have heteroscedasticy. 


\section{MULTIPLE REGRESSION ANALYSIS}

\section{T test}

This $\mathrm{t}$ test is often used to determine whether in the independent variable regression model $(\mathrm{X} 1, \mathrm{X} 2, \ldots \mathrm{Xn})$ partially has a significant effect on the dependent variable $(\mathrm{Y})$. The results of the research data are as follows:

Table $1 \mathrm{~T}$ test Result

\begin{tabular}{|c|c|c|c|c|c|c|}
\hline \multirow[b]{2}{*}{ Model } & & \multicolumn{2}{|c|}{$\begin{array}{l}\text { Unstandardized } \\
\text { Coefficients }\end{array}$} & \multirow{2}{*}{$\begin{array}{l}\text { Standardized } \\
\text { Coefficients } \\
\text { Beta }\end{array}$} & \multirow[b]{2}{*}{$\mathrm{t}$} & \multirow[b]{2}{*}{ Sig. } \\
\hline & & $\mathrm{B}$ & Std. Error & & & \\
\hline \multirow[t]{5}{*}{1} & (Constant) & 5.361 & 1.144 & & 4.688 & .000 \\
\hline & CONCOF & .276 & .051 & .318 & 8.615 & .000 \\
\hline & EXPRES & .100 & .067 & .080 & 1.488 & .138 \\
\hline & HELP & .136 & .055 & .154 & 2.477 & .014 \\
\hline & CITRA & .619 & .072 & .426 & 5.422 & .000 \\
\hline
\end{tabular}

a. Dependent Variable: KPBKJ

source: result of SPSS data Processing

From the table result above it can be seen the regression equation and the relationship of each independent variable to the dependent variable:

$$
\begin{array}{llcccc}
\hat{\mathrm{Y}} & =5,361 & +0,276 \text { CONCOF }+0,100 \text { EXPRES + 0,136 HELP + } & \text { 0,619 CITRA } \\
\mathrm{t}_{\text {count }} & =(4,688) & (8,615) & (1,488) & (2,477) & (5,422) \\
\mathrm{Sig} & =(0,000) & (0,000) & (0,138) & (0,014) & (0,000)
\end{array}
$$

a) The First Hypothesis (H1): : Concern for Other has a positife influence to tourism visiting decision to Tikus Island

From the results of the test, the value of tcount for CONCOF $(\mathrm{X} 1)(8,615)>t$ table $(1,966)$ and the value of sig is obtained. $(0,000)<\alpha(0,05)$, then $\mathrm{H} 0$ is rejected and $\mathrm{Ha}$ is accepted, meaning that Concern for Other (X1) has a significant effect on the decision to visit tourists to rats. Variable Concern for Other (X1) has a positive effect, meaning that every increase in Concern for Other (X1) is $1 \%$, the visiting decision will increase by $0,276 \%$, ceteris paribus. The results of this study are in accordance with the research put forward by Jeonga (2011), this is probably due to the large number of users of social media accounts who have used their accounts to the maximum and there is concern for others to give the impression of the tourist destination they have visited. Users of social media accounts can provide positive and negative experiences, with the hope that they can be used as a reference or input for visitors to tourist destinations.

b) The Second Hypothesis (H2): Expressing positive filling (X2) has an influence on the decision to visit tourists to Tikus Island.

From the results of the test, the tcount EXPRES (X2) $(1,488)<$ ttable $(1,966)$ and the sig value are obtained. $(0.138)>\alpha(0.05)$, the Expressing positive filling (X2) variable is stated to have no effect and is significant for the decision to visit tourists to the rat island. The results of this study are not in accordance with Jeonga (2011) research in Sari (2012) which states that satisfying experiences can trigger consumer interest in visiting. This may be because many social media users are smarter in filtering out news or information that is widespread on social media. So that users do not easily believe the information that exists before they experience or even experience their own experience visiting these attractions

c) The Third Hypothesis (H3): Helping the company (X3) has an influence on the decision to visit tourists to Tikus Island.

From the results of the test obtained tcount HELP (X3) $(2.477)>t$ table $(1,966)$ and the value of sig. $(0.014)<\alpha(0.05)$, the variable Helping the company (X3) was stated to have a significant effect on the decision to visit tourists to the rat island. The variable Helping the company (X3) has a positive effect, meaning that every increase 


\section{ELECTRONIC WORTH OF MOUTH AND DESTINATION IMAGE AND IT'S AFFECTS ON VISITING TOURISTS DECISION IN THE TIKUS ISLAND}

in Helping the company (X3) is $1 \%$, the visiting decision will decrease by $0.136 \%$, ceteris paribus research is in accordance with hasan (2015) research which states one form of customer satisfaction with services provided by the company by helping to publish online. Satisfied consumers can by themselves or voluntarily provide information about the company to other parties, both online and offline. This form of mouth-to-mouth communication is intended to help promote the company.

d) The Fourth Hypothesis (H4): Destination Image (X4) has an influence on the decision to visit tourists to Tikus Island.

From the results of the test, it was obtained the CITRA (X4) tcount $(5,422)>t$ table $(1,966)$ and the sig value. $(0,000)>\alpha(0,05)$, the Destination Image variable $(\mathrm{X} 4)$ is stated to have a significant effect on the decision to visit tourists to the rat island. The Variable Destination Image (X4) has a positive effect, meaning that every increase in the Destination Image (X4) by $1 \%$, the visiting decision will increase by $0.619 \%$, ceteris paribus. The results of the study are in accordance with Isnaini's research (2018). come visit. This might happen because the image of a positive tourist destination on social media will attract consumers who seek satisfaction from the results of the photos and videos they upload on social media.

2. F Test

The $\mathrm{F}$ test is used to determine the effect of independent variables (X) together (simultaneous) on the dependent variable (Y). In the study of independent variables (X), namely: Concern for Other (X1), Expressing positive filling (X2), Helping the company (X3) and Destination image (X4). While the dependent variable is the visiting decision (Y). As for the results of the research data as follows:

Table 2 F Test Result

ANOVA $^{\mathrm{a}}$

\begin{tabular}{lllllll}
\hline & & Sum & of & & & \\
Model & & Squares & df & Mean Square & F & Sig. \\
\hline 1 & Regression & 1162.865 & 4 & 290.716 & 40.956 & $.000^{\mathrm{b}}$ \\
& Residual & 2690.258 & 379 & 7.098 & & \\
& Total & 3853.122 & 383 & & & \\
\hline
\end{tabular}

a. Dependent Variable: KPBKJ

b. Predictors: (Constant), CITRA, CONCOF, EXPRES, HELP

source: result of SPSS data Processing

The results of the F statistic test indicate whether all independent variables are have influencing together to dependent variable. Such as seen in table 2, obtained the value of $F$ count $(40,956)>F_{\text {table }}(5.65)$ with a value of sig $(0,000)<\alpha(0.05)$, then the decision that the independent variables Concern for Other (X1), Expressing positive filling (X2), Helping the company (X3) and Destination image (X4) simultaneously / simultaneously influence the dependent variable of the visiting decision $(\mathrm{Y})$. This is in accordance with the fifth hypothesis (H5): There are influences of Concern for Other (X1), Expressing positive filling (X2), Helping the company (X3) and Destination Imagery (X4) variables simultaneously on visiting (Y) tourists to the Tikus Island.

Table 3

Model Summary ${ }^{b}$

\begin{tabular}{lrrrrr}
\hline Model & R & R Square & $\begin{array}{c}\text { Adjusted R } \\
\text { Square }\end{array}$ & $\begin{array}{l}\text { Std. Error of } \\
\text { the Estimate }\end{array}$ & $\begin{array}{l}\text { Durbin- } \\
\text { Watson }\end{array}$ \\
\hline 1 & $.549^{\mathrm{a}}$ & .302 & .294 & 2.664 & 2.133 \\
\hline
\end{tabular}

a. Predictors: (Constant), CITRA, CONCOF, EXPRES, HELP

b. Dependent Variable: KPBKJ

From table 3 the value of R2 (R Square) $=0.302(30.2 \%)$ can be seen, this shows that Concern for Other (X1), Expressing positive filling (X2), Helping the company (X3) and Destination image (X4) ) can only explain visiting decisions (Y) of $30.2 \%$ and the remaining $69.8 \%$ is influenced by other independent variables not used 
in this study. To find out which variable is the most dominant one influencing the decision to visit tourists in mouse islands can be seen from the value of $\beta$ in the coefficient table. From the SPSS output, the following data are obtained:

Table 4

\section{Coefficients $^{\mathrm{a}}$}

\begin{tabular}{|c|c|c|c|c|c|c|}
\hline \multirow[b]{2}{*}{ Model } & & \multicolumn{2}{|c|}{$\begin{array}{l}\text { Unstandardized } \\
\text { Coefficients }\end{array}$} & \multirow{2}{*}{$\begin{array}{l}\begin{array}{l}\text { Standardized } \\
\text { Coefficients }\end{array} \\
\text { Beta }\end{array}$} & \multirow[b]{2}{*}{$\mathrm{t}$} & \multirow[b]{2}{*}{ Sig. } \\
\hline & & $\mathrm{B}$ & Std. Error & & & \\
\hline 1 & (Constant) & 5.361 & 1.144 & & 4.688 & .000 \\
\hline & CONCOF & .276 & .051 & .318 & 8.615 & .000 \\
\hline & EXPRES & .100 & .067 & .080 & 1.488 & .138 \\
\hline & HELP & .136 & .055 & .154 & 2.477 & .014 \\
\hline & CITRA & .619 & .072 & .426 & 5.422 & .000 \\
\hline
\end{tabular}

a. Dependent Variable: KPBKJ

From the results of table 4 above, it can be seen that the Concern for Other $(\mathrm{X} 1)=$ $0.276(27.6 \%)$, Expressing positive filling $(\mathrm{X} 2)=0.100(10 \%)$, Helping the company $(\mathrm{X} 3)=0.136(13,6 \%)$ and destination image $(\mathrm{X} 4)=0.619(61.9 \%)$. So that the destination image variable (X4) has the most dominant influence on the tourists the decision to visit Bengkulu Tikus Island. This is because the existence of a positive destination image that is disseminated through social media will increasingly attract tourists visiting interest. As well as the development of technological advancements, it is easier for the public to be able to access various information and tourism potential found on Bengkulu Tikus Island.

\section{CONCLUSION AND RECOMENDATIONS}

From the results of these studies, conclusions can be drawn as follows: Partially the Concern for Other $(\mathrm{X} 1)$ variable $(8,615)>t$ table $(1,966)$ and the sig value. $(0,000)$ $<\alpha(0.05)$, Helping the company $(\mathrm{X} 3)(2,477)>$ ttable $(1,966)$ and sig. $(0.014)<\alpha(0.05)$ and destination image $(\mathrm{X} 4)(5,422)>t$ table $(1,966)$ and sig. $(0,000)>\alpha(0,05)$ has a significant positive effect on the variable visiting decision (Y). Simultaneously Concern for Other (X1), Expressing positive filling (X2), Helping the company (X3) and Destination image (X4) variables have influence on the dependent variable of visiting decision (Y) with Fcount value $(40,956)>$ Ftable $(5.65)$ and sig $(0,000)<\alpha$ (0.05). From the partial coefficient table can be seen, that the variable destination image (X4) has the most dominant influence on the tourists decision to visit Bengkulu Tikus Island, This is because consumers will decide to do more tourist visits based on the positive image of tourism objects that will be on go to.

The suggestions that can be given by the author are as follows: In further research, it is necessary to add other external factors that can influence visiting decisions such as improving the quality of tourist destinations both from facilities and infrastructure, local governments can work with tour and travel to be able to publish Tikus Island attractions by making tour packages for Tikus Island destinations. In line with the Wonderful Bengkulu 2020 program, the regional government regularly holds photo or video contests about Bengkulu Tikus Island tourism objects, in order to attract local and foreign tourists and upload them to social media. Improve facilities on Tikus Island such as building places of worship and other public facilities, so that consumers can feel comfortable and satisfied when visiting Tikus Island. The government can upgrade ship transportation which was once confessional to be a glass bottom vessel where the lower part of the ship's hull is made of tempered glas. So that allows tourists to enjoy the beauty of coral reefs and various types of fish found on Tikus Island from a different perspective. Further research can be done on foreign tourists so that they can find out about the influence of Electronic Worth of Mouth (eWOM) and the image 


\section{ELECTRONIC WORTH OF MOUTH AND DESTINATION IMAGE AND IT'S AFFECTS ON VISITING TOURISTS DECISION IN THE TIKUS ISLAND}

of Pulau Tikus tourist destinations in the minds of foreign tourists, so that the government and other related parties can plan a more appropriate marketing strategy.

\section{References}

Arafat, w. (2006). Behind a Powerfull Image. Yogyakarta: Andi Offset

Coban, S. (2012). The Effects of the Image of Destination on Tourist Satisfaction and Loyalty: The Case of Cappadocia. European Journal of Social Science, 29(2): 222-232

Echtner, C. M., \& Ritchie, J. B. (2003). The meaning and measurement of destination image. Journal of Tourism Studies, 14(1), 37-48.

Fandeli, C. (1997). Dasar-dasar Manajemen Kepariwisataan Alam. Liberty.Yogyakarta.

Fakeye, P. C., \& Crompton, J. L. (1991). Image differences between prospective, firsttime, and repeat visitors to the Lower Rio Grande Valley. Journal of Travel Research, 30(2), 10-16.

Ferdinand, A. (2006). Structural Equation Modelling Dalam Penelitian Manajemen Aplikasi Model-Model Rumit Dalam Penelitian Untuk Tesisi Magister Dan Disertasi Doctor. Semarang:BP UNDIP.

George, D. M. (2003). SPSS for Windows Step by step : A Simple Guide and Reference 11.0 update. Allyn and Bacon. Boston

Goodrich, J. N. (1978). The relationship between preferences for and perceptions of vacation destinations: Application of a choice model. Journal of Travel Research, Fall, 8-13

Hadi, S., \& Herawati, A. F. (2013). Pengaruh Tingkat Asosiasi Merek Terhadap Tingkat Kesediaan Melakukan E-Word Of Mouth (Studi Eksplanatif Pengaruh Tingkat Asosiasi Merek Produk Fashion Bonvieux Terhadap Tingkat Kesediaan Melakukan e-Word Of Mouth). Yogyakarta UAJY

Hanif, A. (2010). Pengaruh Citra Destinasi Terhadap Kepuasan Wisatawan Serta Dampak Terhadap Loyalitas Wisatawan ( Studi Pada Wisatawan Nusantara Yang Berkunjung Ke Kota Baru). Fakultas Ilmu Administrasi. Universitas Brawijaya

Hasan, A. (2014). Marketing Dan Kasus-Kasus Pilihan. Yogyakarta : Center for academic Publiding Service.

Hasan, A., \& Setianingtiyas, N. W. (2015). Pengaruh Electronic Word Of Mouth Pada Media Sosial Facebook Terhadap Keputusan Berkunjung Kedesa Wisata Nglageran Gunung Kidul. Jurnal Media Wisata, 13(1), 224-238.

Henkel, R., Henkel, P., Agrusa, W., Agrusa, J., \& Tanner, J. (2006). Thailand as a tourist destination: Perceptions of international visitors and Thai residents. Asia Pacific Journal of Tourism Research, 11, 269-287.

Jasen, B. J. (2009). Twitter Power: Tweets as electronic word of Mouth. Journal of the American Society for Information Science and Tecnology.

Jeonga, E., \& Jang, S. C. (2011). Restaurant Experiences Triggering Positive Electronic Word-Of-Mouth (Ewom) Motivations. International Journal of Hospitality Management, 30, 356-366. 
Kotler, P. (2000). Manajemen Pemasaran di Indonesia Analisis Perencanaan, Implementasi, dan Pengendalian. Dialih bahasakan oleh A.B Susanto. Jakarta: Salemba Empat.

Lee, J., Park, D. H., \& Han, I. (2008). The effect of negative online consumer reviews on product attitude: An information processing view. Electronic commerce research and applications

Malita, L. (2010). Social Media: Time Management Tools and Tips. Procedia Computer Science, 3, 747-753.

Musay, F. P. (2013). Pengaruh Brand Image Terhadap Keputusan Pembelian: Survei pada Konsumen KFC Kawi Malang. Universitas Brawijaya. Malang

Nugraha, M. R. (2013). Analisis Pengaruh Electronic Word Of Mouth,Argument Quality, Message Source Credibility Terhadap Brand Image Dan Dampaknya Pada Purchase Intention. [Tesis]. Jakarta: Binus University

Rao, P. (1996). Measuring Consumer Perseption Through factor Analysis. The Asian Manager, Februari-March, 28-32

Santoso, U. (2009). Bengkulu Menuju Kota Pariwisata. Jurnal Bengkulu Mandiri. http:/usantoso.wordpres.com. Accesed on June 122016.

Sari,V. M. (2012). Pengaruh Electronic Worth Of Mouth (eWOM) di media Social Media Twitter Terhadap Minat Beli Konsumen (studi pada restoran Holycowsteak). [Skripsi]. Jakarta :FISIP UI.

Semuel, H., \& Lianto, A. S. (2014). Analisis eWOM, Brand Image, BrandTrust dan Minat Beli Produk Smartphone di Surabaya. Jurnal Manajemen Pemasaran, $8(2), 47-54$

Sustirahmah. (2013). Eksistensi Pulau Tikus. http:// www.kompasiana. com/ sustirahmah/ eksistensi-pulau-tikus. Accesed on June 122017.

Yuksel, A., Yuksel, F., \& Bilim, Y. (2010). Destination attachment: Effects on customer satisfactionand cognitive, affective and conative loyalty. Tourism Management, 31(2), 274-284.

Undang-Undang Republik Indonesia Nomer 10 Tahun 2009 tentang Kepariwisataan. https://bengkulu.bps.go.id/Brs/view/id/153 (Accesed on Juni 8 2017)

http://www.ppk-kp3k.kkp.go.id/direktopulau/index.php/public_c/pulau_info/1749 (Accesed on June 11 2017)

http://www.unib.ac.id/2017/04/seminar-nasional-potensi-pariwisata-baharmenujuwonderful-bengkulu-2020. (Accesed on June 10 2017) 